УДК 37:001.12/.18

(C) Шаповал В. В., 2021 p.

http://orcid.org/0000-0002-9219-2278

DOI: $10.34142 / 23128046.2021 .51 .17$

В. В. Шаповал

\title{
ПОНЯТТЯ «ПРОФЕСІЙНА РЕАБІЛІТАЦІЯ УЧАСНИКІВ БОЙОВИХ ДІЙ ЗСУ»
}

У статті розглянуто поняття професійної реабілітачії учасників бойових дій ЗСУ. Сочіально-психологічна реабілітація - прочес організованого соиіальнопсихологічного впливу, спрямованого на відновлення такого стану психічного здоров'я воїнів, який знову дозволить їм успішно вирішувати бойові та службові завдання чи бути потрібним в мирному житті. Ця діяльність, спрямована на відновлення психічних функцій й особистісного статусу людини, порушеного внаслідок дії психотравмуючих факторів, з використанням методів і процедури психотерапії. Сочіально-реабілітаційні заходи проводяться, як правило, в системі реабілітаційних програм, що допускає не тільки спеціалізовану медичну і психологічну допомогу, але і створення необхідних сочіальних умов.

3'ясовано, щзо для забезпечення результативності прочесу комплексної реабілітації військовослужбовиів-учасників бойових дій необхідно розробити й адаптувати реабілітаційні технології, котрі допоможуть здійснити широкий спектр сочіально-економічних та медико-соиіальних заходів.

У статті представлено різноманітні реабілітаційні технологї̈, які можна використовувати у роботі з військовослужбовиями-учасниками бойових дій, а саме: соиіальні технології, котрі безпосередньо спрямовані на вирімення загальнолюдських проблем, щчо пов'язані з оцінкою не тільки внутрішніх, але й світових тендениій розвитку, зв'язку суспільства з природою. Їх впровадження пов'язано з життям людей, їх життєдіяльністю та соціальною захищеністю; інновачійні сочіальні технології, які зосереджені на створенні та матеріалізаиії нововведень у суспільстві, реалізаиії таких ініціатив, котрі викликають якісні зміни в різних сферах соиіального життя, призводять до раціонального використання матеріальних та інших ресурсів у суспільстві; регіональні, що передбачають вивчення ци реалізацію закономірностей територіальної організаиіі соціального життя та його планомірних змін; інформаційні охоплюють засоби, прийоми, оптимізацію інформаційного процесу, його відтворення; інтелектуальні, котрі спрямовані на стимулювання розумової діяльності людей, розвиток їхніх творчих здібностей.

Ключові слова: професійна реабілітація, військовослужбовиі, розробка технологій, комплексна допомога, комплекс реабілітаиійних засобів, соціальні, психологічні та медичні заходи, сочіальна адаптація.

Shapoval $V . V$. The concept of "professional rehabilitation of participants of the military operation of the Armed Forces of Ukraine". In the article we will 
consider the concept of professional rehabilitation of participants in hostilities of the Armed Forces. Socio-psychological rehabilitation is a process of organized sociopsychological influence aimed at restoring the state of mental health of soldiers, which will again allow them to successfully solve combat and service tasks or be needed in a peaceful life. This activity is aimed at restoring the mental functions and personal status of a person disturbed as a result of traumatic factors, using the methods and procedures of psychotherapy. Social rehabilitation measures are carried out, as a rule, in the system of rehabilitation programs, which allows not only specialized medical and psychological care, but also the creation of the necessary social conditions.

It has been found that it is necessary to develop and adapt rehabilitation technologies that will help to implement a wide range of socio-economic and medicalsocial measures in order to ensure the effectiveness of the process of comprehensive rehabilitation of members of armed forces.

The article presents a variety of rehabilitation technologies that can be used to work with members of armed forces, namely social technologies that are directly aimed at solving universal problems related to the assessment of not only inner but also global development trends, so-called connection of society with nature. Their implementation is related to people's lives, activities of their daily living and social security; innovative social technologies which are focused on the creation and materialization of innovations in society, the implementation of such initiatives that cause qualitative changes in various spheres of social life and lead to the rational use of material and other resources in society; regional technologies that involve the study and implementation of the laws of territorial organization of social life and its planned changes; information technologies include tools, techniques, optimization of the information process, its reproduction; intellectual ones which are aimed at stimulating the mental activity of people, the development of their creative abilities.

Key words: vocational rehabilitation, servicemen, technology development, complex assistance, complex of rehabilitation means, social, psychological and medical measures, social adaptation.

Вступ. Військові Збройних Сил України, котрі беруть участь у бойових діях, потребують постійної соціальної уваги, створення системи комплексної реабілітації.

Узагальнення статистичних матеріалів свідчить про те, що за період війни на Донбасі в Українській державі з'явилося понад 320 тисяч ветеранів, котрі потребують комплексної допомоги з метою інтеграції в суспільство. Зазначений процес вимагає створення такої системи реабілітації, котра б включала як медичну, соціальну, психологічну, так й інші види реабілітації. Існуючий в українському суспільстві комплекс заходів, які надають соціальні служби щодо реабілітації військовослужбовців, ветеранів бойових дій, носить частковий, безсистемний та фрагментарний характер (Shakhrai, 2017).

Таке положення речей $є$ результатом недосконалості соціального захисту (правового, економічного, соціального, психологічного, медичного) 
військовослужбовців. Нажаль, незадоволеність військовослужбовців своїм становищем у суспільстві, посттравматичний психічний розлад, високий відсоток суїцидів, психічне неблагополуччя $є$ наслідками, що не дають можливості військовим - учасникам бойових дій - повною мірою реалізувати свій потенціал в мирних умовах. Важливу роль в цьому процесі відіграють спеціалізовані соціальні служби і установи реабілітації, котрі покликані забезпечити гарні умови щодо успішної реабілітації зазначеної категорії військових.

Мета та завдання. Мета статті полягає у з'ясуванні суті поняття «професійна реабілітація» та теоретико-методологічному обгрунтуванні організації комплексної реабілітації військовослужбовців - учасників бойових дій.

Методи дослідження. Під час проведення дослідження використано комплекс методів, який включає як загальнонаукові (аналіз, синтез, узагальнення), що дозволили визначити суть поняття «професійна реабілітація», так і порівняльно-зіставний, котрий дав можливість порівнювати та зіставляти думки науковців щодо поняття, яке вивчається.

Результати. Військові події на Сході України викликали потребу у необхідності створити систему соціальної адаптації та реабілітації військовослужбовців, яка б динамічно розвивалась, уміла швидко і гнучко реагувати на законодавчо-правові положення, перебудовуючи реабілітаційні установи для втілення в життя реабілітаційних заходів на державному та регіональному рівнях через розгалужену мережу органів державної влади, місцевого самоврядування, громадських організацій. Вважається, що комплексна система реабілітації військовослужбовців - учасників бойових дій повинна бути спрямована як на реабілітацію інвалідів, так і осіб, які не мають інвалідності, але об'єктивно її потребують, і включати в себе органи управління процесом соціальної реабілітації і реабілітаційні установи (Bryndikov, 2018).

3 метою розробки технології організації і проведення комплексної реабілітації військових - учасників бойових дій, відокремимо їі складові, при цьому акцентуємо головну увагу на вивченні категоріального апарату досліджуваного феномену. Так, у науково-довідкових джерелах поняття «технологія» (techne - мистецтво i logia - вчення) виступає синтезом методів оброблення, виготовлення, суттєвої зміни стану, властивостей і форми об'єкту. Технологію розуміють як «синтез методів, засобів i реалізації людьми конкретного складного процесу шляхом поділу його на систему послідовних взаємопов'язаних процедур і операцій, які виконуються більш або менш однозначно і мають на меті досягнення високої ефективності певного виду діяльності» (Shkliarskyi, 2019; Shkliarskyi, 2018). Наголосимо на тому, що 
технологія завжди передбачає певну логіку, послідовність реабілітаційних форм, методів i прийомів, виконання яких сприяє отриманню запланованих результатів.

Поділяємо думку О. Серповської у тому, що реабілітаційний процес військових - учасників бойових дій - виступає системою як наукової, так і практичної діяльності, спрямованої на відновлення особистісного і соціального статусу кожного учасника шляхом комплексного впливу на нього iз використанням засобів медичного, соціального, психологічного, педагогічного, правового й іншого впливу.

Кінцевим результатом використання реабілітаційних заходів О. Серповська визначила необхідність досягнення оптимального рівня соціально-психічної адаптованості військових - учасників бойових дій, а технології, методи і прийоми повинні бути спрямовані на відновлення адаптивних функцій особистості.

Для забезпечення результативності процесу комплексної реабілітації військових - учасників бойових дій, необхідно розробити й адаптувати реабілітаційні технології, які допоможуть здійснити широкий спектр_соціальноекономічних та медико-соціальних заходів для розв'язання проблем цієї категорії населення. Серед різноманіття реабілітаційних технологій, які можна використовувати у роботі з військовослужбовцями - учасниками бойових дій, дослідники виділяють такі:

1) соціальні технології, які безпосередньо спрямовані на вирішення загальнолюдських проблем, що пов'язані з оцінкою не тільки внутрішніх, але й світових тенденцій розвитку, зв'язку суспільства з природою. Їх впровадження пов'язано з життям людей, їхньою життєдіяльністю та соціальною захищеністю;

2) інноваційні соціальні технології, зосереджені на створенні і матеріалізації нововведень у суспільстві, реалізації таких ініціатив, які викликають якісні зміни в різних сферах соціального життя, призводять до раціонального використання матеріальних та інших ресурсів у суспільстві;

3) регіональні, які передбачають вивчення і реалізацію закономірностей територіальної організації соціального життя і його планомірних змін;

4) інформаційні - охоплюють засоби, прийоми, оптимізацію інформаційного процесу, його відтворення;

5) інтелектуальні, спрямовані на стимулювання розумової діяльності особистості, розвиток іiі творчих здібностей.

Розуміючи під технологію процес, певний алгоритм послідовних дій, проаналізуємо різні наукові підходи до розуміння технології реабілітації військовослужбовців (Chyzhov, 2016). Зокрема, Н. Алаликіна пропонує алгоритм реабілітації військовослужбовців, який складається з трьох етапів. 
Так, перший етап передбачає з'ясування наслідків травмувальних факторів, а саме:

- виявлення стрес-факторів, що викликають негативні психологічні наслідки;

- дослідження індивідуально-психологічних особливостей військовослужбовців як до призову в Збройні Сили, так і під час служби;

- вивчення впливу соціально-психологічних чинників повоєнної адаптації;

- дослідження актуальних психічних реакцій, які в минулому мали травмувальний вплив.

3 метою вивчення психологічних наслідків участі у бойових діях першорядним завданням виступає аналіз досвіду військового, котрий спричинив появу психічної травми. 3 цією метою науковець пропонує використання розгорнутого клінічного інтерв'ю, котре запропоноване Р. Скерфілдом (R. Skurfield) і А. Бланком (A. Blank).

При з'ясуванні наслідків травмувальних чинників обов'язково необхідно враховувати, по-перше, те, що чим більше ветеран був залучений до бойових дій, тим він більше схильний до насильницьких дій, зловживання алкоголю і наркотиків. По-друге, доцільно аналізувати індивідуально-психологічні особливості і життєві обставини до призову в армію; взаємодію специфіки передвоєнного життя військовослужбовця та його бойового досвіду; значення $\mathrm{i}$ вплив соціально-психологічних умов повоєнної адаптації.

Другий етап спрямований на визначення комплексу психотерапевтичних впливів на військовослужбовців - учасників бойових дій - для корекції психотравмувальних реакцій, організації психологічної реабілітації. На зазначеному етапі необхідно детально вивчити психічні реакції, які в минулому мали психотравмувальний характер.

Третій етап зосереджений на організації соціально-психологічної адаптації до нового середовища. При цьому слід брати до уваги той факт, що досить часто та частина військових, котра більшою мірою потребує соціальної та психологічної підтримки, відчужуються від сім’ї і друзів. Вивчаючи це явище, Д. Вільсон (J. Wilson) приходить до висновку, що вони споруджують навколо себе так званий запобіжний «заслін» 3 метою збереження контролю над ступенем інтимних переживань, пов'язаних зі значущими подіями та людьми. Він вважає, що це прагнення до психологічної дистанції і відстороненості пов'язане 3 військовим досвідом, і вже в мирних умовах військовий - учасник бойових дій продовжує контролювати ступінь інтимних відносин, щоб знову не відчути душевний біль, пов'язаний із втратою близької людини. Зазначене явище супроводжується конфліктами 3 близьким, виявляється в напруженості й дратівливості (Shevchuk, 2016). 
Оскільки у складі комплексної реабілітації доволі часто виокремлюють соціально-психологічний напрям, то ми представляємо етапи його практичного здійснення:

- встановлення характеру і ступеня вираженості нервово-психічного розладу та особливостей реагування на психічну травму;

- з'ясування психічних порушень особистості і запровадження індивідуальних заходів реабілітаційного впливу;

- швидке зняття психоемоційної напруги, дратівливості, страху;

- регуляція зіпсованих функцій організму людини;

- мобілізація особистості для подолання станів, що виникають;

- відновлення (корекція) соціального статусу військовослужбовця;

- стимулювання соціальної активності особистості;

- професійна реабілітація та переорієнтація;

- орієнтир на продовження активної діяльності;

- контролювання психічних станів і корекція реабілітаційних заходів.

Психологічна реабілітація, на думку В. Попова, відбуватиметься ефективніше за умов дотримання таких етапів, як:

- вступний;

- підготовчий;

- катарсичний;

- розуміння та усвідомлення екстремальної поведінки;

- формування нових навичок поведінки;

- визначення життєвих перспектив;

- проведення підтримувальних заходів (Pavliuk, Prystupa \& Startsun, 2017).

Обговорення. Проведене дослідження підтверджує висновки фахівців про те, що професійна реабілітація учасників бойових дій спрямована, насамперед, на відновлення психічних функцій та особистісного статусу людини, який порушено в результаті впливу психотравмуючих чинників, із використанням методів та процедури психотерапії.

Висновки. Дослідниками 3'ясовано, що поняття «реабілітація» тісно пов'язане 3 адаптацією, реадаптацією, переадаптацією, дезадаптацією, ресоціалізацією, психологічною допомогою. На сьогоднішній день термін «реабілітація» широко використовується в різних галузях, як-от: медицина, соціологія, психологія, педагогіка, психіатрія.

У соціальному розумінні реабілітація пов'язана з відновленням здоров'я особистості, іï соціального положення, котре було втрачено або знижено в наслідок проблем, які призвели до важкої ситуації. В галузі медицини під реабілітацією розуміють процес, що спрямований на відновлення фізичних та духовних сил особистості, іiі професійних навичок. В широкому значенні 
реабілітацію розглядаємо як самостійний вид соціальної діяльності уповноважених представників держави, соціальних служб та об'єднань громадян i інших соціальних інституцій, котра безпосередньо орієнтована на проведення організаційної, економічної, правової, культурної, освітньої, лікувальної, оздоровчої і іншої соціальної допомоги з метою покращення як фізичного i функціонального стану, так і відновлення працездатності, честі та гідності, прав та свобод окремих категорій населення, що були порушені хворобами, травмами, фізичними, хімічними й іншими соціальними факторами. Процес реабілітації традиційно відбувається у різних закладах соціально-медичного спрямування, як-от: кризових центрах, відділеннях ранньої соціальної реабілітації та соціально-психологічної реабілітації; реабілітаційних центрах спеціалізованої допомоги; військових шпиталях, притулках, закладах лікувального та спеціалізованого спрямування.

Головну увагу акцентовано на характеристиці комплексного аспекту реабілітації, так як вона виступає системою наукової і практичної діяльності, котра спрямована на відновлення особистісного і соціального статусу військових - учасників бойових дій - шляхом комплексної діяльності 3 широким використанням медичного, соціального, психологічного, педагогічного, правового та іншого впливу.

Реабілітацію військових - учасників бойових дій - розглядаємо як використання цілісного комплексу медичного, фізичного, психологічного, соціального, педагогічного впливів, які спрямовані на відновлення у даної категорії здоров’я, емоційного стану, працездатності, значного покращення процесу соціалізації й адаптації до життєвих умов.

\section{ЛІТЕРАТУРА:}

Бриндіков Ю. Л. Реабілітація військовослужбовців учасників бойових дій в системі соціальних служб: теоретико-методичні основи: монографія. Хмельницький: Вид-во «Поліграфіст», 2018.

Основи соціальних знань. Навчальний посібник. Під загальною редакцією Ю. О. Шклярського. Миколаїв: Видавництво «КВIТ», 2019.

Чижов Д. А. Нормативно-правове забезпечення права на соціальний захист учасників АТО та членів їх родин. Вісник Національного університету «Львівська політехніка». Серія: Юридичні науки. 2016.

Шахрай В. М. Технології соціальної роботи. Навчальний посібник. К. : Центр навчальної літератури, 2017.

Основи соціальних знань. Навчальний посібник. Під заг. ред. Ю. О. Шклярського. Миколаїв: Видавництво «КВІТ», 2018.

Павлюк В. Д., Приступа М. І., Старцун В. І. Соціальна політика: Навч. посіб. Хмельницький: ХНУ, 2017.

Шевчук П. І. Соціальна політика: 2-е вид. Львів : Світ, 2016.

\section{REFERENCES:}


Bryndikov, Y. (2018). Reabilitatsiia viiskovosluzhbovtsiv uchasnykiv boiovykh dii v systemi sotsialnykh sluzhb: teoretyko-metodychni osnovy [Rehabilitation of servicemen involved in hostilities in the system of social services: theoretical and methodological foundations]: monohrafiia. Khmelnytskyi: Vyd-vo «Polihrafist» (in Ukranian).

Shkliarskyi, Yu. O. (Ed.) (2019). Osnovy sotsialnykh znan. [Fundamentals of social knowledge]. Navchalnyi posibnyk. Mykolaiv: Vydavnytstvo «KVIT» (in Ukranian).

Chyzhov, D. A. (2016). Normatyvno-pravove zabezpechennia prava na sotsialnyi zakhyst uchasnykiv ATO ta chleniv yikh rodyn. [Regulatory and legal support of the right to social protection of anti-terrorist operation participants and members of their families]. Visnyk Natsionalnoho universytetu «Lvivska politekhnika». Seriia: Yurydychni nauky (in Ukranian).

Shakhrai, V. M. (2017). Tekhnolohii sotsialnoi roboty. [Technologies of social work]. Navchalnyi posibnyk. K. : Tsentr navchalnoi literatury (in Ukranian).

Shkliarskyi, Yu. O. (Ed.) (2018). Osnovy sotsialnykh znan. [Fundamentals of social knowledge]. Navchalnyi posibnyk. Mykolaiv: Vydavnytstvo «KVIT» (in Ukranian).

Pavliuk, V. D., Prystupa, M. I. \& Startsun, V. I. (2017). Sotsialna polityka [Social policy]: Navch. posib. Khmelnytskyi: KhNU (in Ukranian).

Shevchuk, P. I. (2016). Sotsialna polityka [Social policy]: 2-e vyd. Lviv: Svit (in Ukranian).

\section{Інформація про автора:}

\section{Шаповал Віталій Віталійович}

ORCID: http://orcid.org/0000-0002-9219-2278;

здобувач третього (освітньо-наукового) рівня вищої освіти кафедри інноваційних технологій 3 педагогіки, психології та соціальної роботи, Університет імені Альфреда Нобеля, вул. Січеславська Набережна 18, Дніпро, Україна, 49000

e-mail:vitaliy_shapova195@bigmir.net

\section{Information about the author:}

\section{Shapoval Vitalii Vitaliiovych}

ORCID: http://orcid.org/0000-0002-92192278; PhD student of the Department of Innovative Technologies in Pedagogy, Psychology and Social Work, Alfred Nobel University, Sicheslavska Naberezhna 18, Dnipro city, Ukraine, 49000

e-mail:vitaliy_shapova195@bigmir.net

Цитуйте цю статтю як: Шаповал В. В. Поняття «професійна реабілітація учасників бойових дій ЗСУ». Теорія та методика навчання та виховання. 2021. № 51. С. 185-192. DOI: $10.34142 / 23128046.2021 .51 .17$

Дата надходження статті до редакції: 28.09.2021

Стаття прийнята до друку: 12.10.2021 